\title{
Maternal and perinatal outcome of oligohydramnios in term pregnancy in rural tertiary care centre
}

\author{
Swati Kagne ${ }^{1}$, Sambhaji Chate ${ }^{2 *}$ \\ ${ }^{1}$ Department of Obstetrics and Gynecology, ${ }^{2}$ Department of Pediatrics, SRTRGMC, Ambajogai, Maharashtra, India
}

Received: 08 December 2018

Accepted: 02 January 2019

\section{*Correspondence:}

Dr. Sambhaji Chate,

E-mail: drsambhaji@gmail.com

Copyright: $\odot$ the author(s), publisher and licensee Medip Academy. This is an open-access article distributed under the terms of the Creative Commons Attribution Non-Commercial License, which permits unrestricted non-commercial use, distribution, and reproduction in any medium, provided the original work is properly cited.

\begin{abstract}
Background: Disorders of amniotic volume is one of the commonest obstetric problem. Amniotic fluid acts as cushion to the foetus allowing musculoskeletal development and also helps in the differentiation of lungs and gastrointestinal tract. Decreased amniotic fluid, known as oligohydramnios, is known to be associated with adverse perinatal outcome. The objective is to study the maternal and perinatal complications of oligohydramnios in term pregnancy.

Methods: The present study was carried out in the Department of Obstetrics at rural tertiary care hospital in Maharashtra from February 2018 through October 2018. women with Oligohyamnios were studied for obstetrical and neonatal complications.

Results: The incidence of oligohyamnios was $7.6 \%$ in present study. The mean age of the study population was $22.6 \pm 3.6$ years. Induction of labour was required in $44(61.11 \%)$ patients out of which 23 patients underwent emergency LSCS. Low birth weight (birth weight $<2.5 \mathrm{~kg}$ ) was found in $14(19.44 \%)$ babies with 11 babies having intrauterine growth restriction. 5-minute APGAR (appearance, pulse, grimace, activity, respiration) score was $<7$ in $13.88 \%$ babies. 16 babied needed NICU admission out of which 1 neonate died.

Conclusions: Detection of oligohydramnios increases obstetrical interventions in term pregnancy.
\end{abstract}

Keywords: Induction of labour, Oligohydramnios, Perinatal outcome

\section{INTRODUCTION}

Amnionic fluid serves to cushion the fetus, allowing musculoskeletal development and protecting it from trauma. It also maintains temperature and has a minimal nutritive function. Epidermal growth factor (EGF) and EGF-like growth factors, such as transforming growth factor, are present in amnionic fluid. Ingestion of fluid into the gastrointestinal tract and inhalation into the lung may promote growth and differentiation of these tissues. ${ }^{1}$ The volume of amnionic fluid at each week is quite variable. In general, the volume increases by $10 \mathrm{ml}$ per week at 8 weeks and increases up to $60 \mathrm{ml}$ per week at 21 weeks, then declines gradually back to a steady state by 33 weeks. $^{2}$ Normally, amnionic fluid volume reaches 1 litre by 36 weeks and decreases thereafter to less than 200 $\mathrm{mL}$ at 42 weeks. ${ }^{1}$ Diminished amniotic fluid is termed as oligohydramnios. Phelan and colleagues described ultrasonographic quantification of the amniotic fluid using the amnionic fluid index-AFI. ${ }^{3}$ This is calculated by adding the vertical depths of the largest pocket in each of four equal uterine quadrants. Phelan defined oligohydramnios as amniotic fluid index (AFI) $\leq 5 \mathrm{~cm}$ and borderline oligohydramnios as AFI between 5 and $8 \mathrm{~cm}$ between 36-42 weeks of gestation. ${ }^{3}$ Oligohydramnios occurs in about $1-5 \%$ of pregnancies at term. ${ }^{4}$ Oligohydramnios leads to maternal complications like prolonged labor, increased operative interference and fetal complications like abortion, deformity due to intraamniotic adhesions, cord compression. Women with 
oligohydramnios are more likely to have abnormal FHR tracings, increased incidence of fetal distress, and thus an increased incidence of caesarean sections. ${ }^{5}$ The present study was carried out to study the incidence of oligohydramnios and its maternal and perinatal complications in rural tertiary care hospital.

\section{METHODS}

The present study was carried out in the department of obstetrics at rural tertiary care hospital in Maharashtra from February 2018 to October 2018. The study was approved by Institutional Ethics Committee. All the patients were subjected to detailed history, clinical examination, relevant laboratory investigations and ultrasonography for AFI measurement and findings were entered in a predesigned proforma.

\section{Determination of amniotic fluid volume}

A. Clinical assessment: It is subjective with interobserver and intra observer variability

B. Quantitative assessment

\section{- $\quad$ Single deepest pocket measurement}

Dimensions of the largest vertical pocket of amniotic fluid are measured and presence of $<1 \mathrm{~cm}$ pocket of fluid is defined as oligohydramnios.

\section{- $\quad$ Annual Fluid Index (AFI): ${ }^{3}$}

a. Divide the uterus into four quadrants using the linea nigra as the vertical axis and the umbilicus as the horizontal axis

b. The pocket with the largest vertical dimension is measured in each quadrant.

c. Sum of all four measurements=AFI

d. Values are labelled as follows: $<5 \mathrm{~cm}=$ very low (oligohydramnios), 5.1-8cm=low, 8.1-25cm=normal, $>25 \mathrm{~cm}=$ polyhydramnios.

In present study, AFI was calculated by ultrasonography for pregnant women with 37 completed weeks of gestation and those with AFI $\leq 5 \mathrm{~cm}$ was diagnosed as oligohydramnios and included in the study.

\section{Inclusion criteria}

- Women with singleton pregnancy>37weeks gestation with cephalic presentation, $\mathrm{AFI} \leq 5 \mathrm{~cm}$ with intact membranes.

\section{Exclusion criteria}

- Multiple gestation

- Malpresentations

- Fetal malformations

- PROM.

\section{Statistical analysis}

The data was analyzed by Microsoft excel and Epi info version 7 .

\section{RESULTS}

There were 945 full term patients screened for presence of oligohydramnios over a period of 9months. Oligohydramnios $(\mathrm{AFI}<5)$ was present in $72(11.16 \%)$ patients. The mean age of the study population was $22.6 \pm 3.6$ years. $53(73.61 \%)$ patients belonged to the age group of $20-25$ years. $47(65.27 \%)$ patients were primigravida and 25 patients were multigravida. The mean gestational age in present study population was $38.3 \pm 1.6$ weeks. The incidence of oligohydramnios in present study was $7.6 \%$.

\section{Maternal complications}

Induction of labour was required in $44(61.11 \%)$ patients out of which 23 patients underwent emergency LSCS. 32 (44.44\%) patients has non- reassuring NST and in 20 $(27.77 \%)$ patients, amniotic fluid was meconium stained. 2 babies died in utero as depicted (Table 1).

Table 1: Maternal outcome of women with oligohydramnios at term.

\begin{tabular}{|l|l|l|}
\hline $\begin{array}{l}\text { Total patients with } \\
\text { oligohydramnios }\end{array}$ & $\mathbf{N}=72$ & Percentage \\
\hline Vaginal delivery & 32 & 44.44 \\
\hline Induction of labour & 44 & 61.11 \\
\hline Elective LSCS & 17 & 23.61 \\
\hline Emergency LSCS & 23 & 31.94 \\
\hline $\begin{array}{l}\text { Meconium stained amniotic } \\
\text { fluid }\end{array}$ & 20 & 27.77 \\
\hline Non-reassuring NST & 32 & 44.44 \\
\hline IUFD & 2 & 2.77 \\
\hline
\end{tabular}

\section{Fetal and neonatal complications}

Table 2: Fetal and neonatal outcome.

\begin{tabular}{|l|l|l|}
\hline Mother with oligohydramnios & $\mathbf{N}=72$ & Percentage \\
\hline birth weight $<2.5$ & 14 & 19.44 \\
\hline SGA & 11 & 15.27 \\
\hline IUFD & 2 & 2.77 \\
\hline & $\mathbf{N}=\mathbf{7 0}$ & \\
\hline Meconium aspiration & 9 & 12.85 \\
\hline APGAR $<7$ at 5 min & 10 & 14.28 \\
\hline NICU admission & 16 & 22.85 \\
\hline neonatal Death & 1 & 1.42 \\
\hline
\end{tabular}

Low birth weight (birth weight $<2.5 \mathrm{~kg}$ ) was found in 14 $(19.44 \%)$ babies with 11 babies having intrauterine growth restriction. 5-minute APGAR (appearance, pulse, grimace, activity, respiration) score was $<7$ in $14.28 \%$ 
babies. 16 babied needed NICU admission out of which 1 neonate died on $3^{\text {rd }}$ day of life (Table 2).

\section{DISCUSSION}

The study was undertaken in rural tertiary care hospital to study the maternal and perinatal complications of oligohydramnios at term. Pregnant women $>37$ weeks gestation age was screened for oligohydramnios and those with AFI $<5$ were studied for perinatal complications. The mean age of the pregnant women with oligohydramnios in present study is 22.6 years. The mean maternal age was 23.66 years in a study done by Jagatia et al. ${ }^{6}$ In a study done by Casey B et al, mean maternal age of women with oligohydramnios was 23.9 years. In observations made by Chauhan et al and Jun zhang et al, mean maternal age was similar to present study. ${ }^{7,8} 53(73.61 \%)$ patients belonged to the age group of 20-25 years which is similar to findings made by Gabbe et al, and Gita et al. ${ }^{9,10}$

The mean gestational age in present study was $38.3 \pm 1.6$ weeks. The mean gestation age in the study done by Vidyasagar et al, Jun zhang et al and Casey B et al, is 36.3 weeks, $38.1 \pm 3.3$ weeks, $37.5 \pm 2$ respectively. ${ }^{11} 47$ $(65.27 \%)$ patients were primigravida in present study which is in contrast to study done by Bhattacharya et al, who found that one third patients were primigravidae. ${ }^{12}$ The incidence of oligohydramnios was $7.6 \%$ which is higher than that detected by Divon $\mathrm{M}$ et al, (1.2\%) Casey B et al (2.3\%), Elliot $\mathrm{H}$ et al, (3.9\%). ${ }^{5,13,14}$

Induction of labour was required in $61.11 \%$ patients of which $52.27 \%$ underwent emergency LSCS which is similar to findings by Locatelli et al. ${ }^{15}$ Similar finding was noticed in the study done by Jandial et al, in which labour was induced $58 \%$ patients out of which $42 \%$ underwent LSCS. $^{16}$ Labour was induced in $86 \%$ of women of which $61 \%$ underwent LSCS in a study done by Bachhav et al. ${ }^{17}$

Low birth weight was found in 14 babies (19.44\%) in contrast to $64 \%$ by Bachhav et al and $65.3 \%$ by Nazlima et al. ${ }^{17,18}$ In 10 patients, APGAR score was less than 7 at 5 minutes and $22.85 \%$ babies needed NICU admission which is higher than that found by Umbre et al, $(8.1 \%){ }^{19}$ Low birth weight was seen in $48 \%$, Apgar score $<7$ seen in $14 \%$ and $14 \%$ were admitted in NICU in study by According to Sowmya $\mathrm{K}$ et al, $34 \%$ required NICU admission and $20 \%$ had APGAR score $<7$ at 5 minutes in a study done by Madhavi $\mathrm{K}$ et al. ${ }^{20,21}$ An APGAR score of $<7$ at 5 min was seen in $26.9 \%$ of babies in a study by Nazlima et al, $12 \%$ of babies in a study by Jandial et al. ${ }^{16,18}$ Perinatal mortality was $4.1 \%$ which is comparable to that found by Nazlima et al, $(2.4 \%) .{ }^{18}$

\section{CONCLUSION}

Oligohydramnios is detected commonly now a days due to availability of Obstetric ultrasonography. Detection of oligohydramnios increases the number of obstetric interventions like induction of labour, caesarean section which increases the maternal as well as neonatal morbidity. Close monitoring with NST is required once oligohydramnios is detected at term to prevent adverse perinatal outcome.

\section{Funding: No funding sources}

Conflict of interest: None declared

Ethical approval: Not required

\section{REFERENCES}

1. Cunningham F, Leveno K, Bloom S, Hauth J, Rouse D, Spong C. Williams Obstetrics $23^{\text {rd }}$ ed. New York: McGraw-Hill; 2010:2010.

2. Brace RA, Wolf EJ. Normal amniotic fluid volume changes throughout pregnancy. Am J Obstet Gynecol.1989;161(2):382-8.

3. Phelan JP, Smith CV, Broussard P, Small M. Amniotic fluid volume assessment using the fourquadrant technique in the pregnancy at $36-42$ weeks gestation. J Reprod Med. 1987;32(7):540-2.

4. Moore IR. Clinical assessment of amniotic fluid. Clin Obstet Gynaecol. 1997;40:303-13.

5. Casey BM, McIntire DD, Bloom SL, Lucas MJ, Santos R, Twickler DM, et al. Pregnancy outcomes after antepartum diagnosis of oligohydramnios at or beyond 34 weeks of gestation. Am J Obstet Gynecol. 2000;182(4):909-12.

6. Jagatia K, Singh N, Patel S. Maternal and fetal outcome in oligohydramnios: a study of 100 cases. Int J Med Sci Public Health. 2013;2:724-7.

7. Chauhan SP, Hendrix NW. Intrapartum oligohydramnios does not predict adverse peripartum outcome among high risk parturient. Am J Obstet Gynecol. 1997;176(6):1130-6.

8. Zhang J, Troendle J. Isolated oligohydramnios is not associated with adverse perinatal outcome. Int $\mathbf{J}$ Gynaecol Obstet. 2004;3:220-5.

9. Gabbe SG, Niebyl JR, Simpson JL, Landon MB, Galan HL, Jauniaux ER, et al. Obstetrics: normal and problem pregnancies e-book. Elsevier Health Sciences; 2016.

10. Gita G, Shweth P, Arvind L, Shashi K. A prospective clinical study of feto-maternal outcome of pregnancies with abnormal liquor volume. J Obstet Gynaecol India. 2011;61(6):652-5.

11. Vidyasagar V, Chutani N. Fetomaternal outcome in cases of oligohydramnios after 28 weeks of pregnancy. Int J Reprod Contracept Obstet Gynecol. 2015;4:152-6.

12. Bhattacharya R, Akshaya S. Fetomaternal outcome in patients with oligohydromnions in a tertiary hospital. Int J Reprod Contracept Obstet Gynecol. 2016;5:2576-80.

13. Divon MY, Marks AD, Henderson CE. Longitudinal measurement of amniotic fluid index in postterm pregnancies and its association with fetal outcome. Am J Obstetr Gynecol. 1995;172(1):142-6. 
14. Philipson EH, Sokol RJ, Williams T. Oligohydramnios-Clinical association and predictive value for intrauterine growth retardation. Am J Obstet Gynecol. 1983;146(3):271-8.

15. Locatelli A, Vergani P, Toso L, Verderio M, Pezzullo JC, Ghidini A. Perinatal outcome associated with oligohydromnios in uncomplicated term pregnancies. Arch Gynecol Obstet. 2004;269(2):1323.

16. Jandial C, Gupta S, Sharma S, Gupta M. Perinatal outcome after antepartum diagnosis of oligohydramnios at or beyond 34 weeks of gestation. JK Sci. 2007;9(4):213-4.

17. Bachhav AA, Waiker M. Low amniotic index at term as a predictor of adverse perinatal outcome. J Obstet Gynaecol India. 2014;64(2):120-3.

18. Nazlima N, Fathima B. Oligohydromnios at third trimester and perinatal outcome. Bangla J Med Sci. 2012;11(1):33-6.
19. Umber A. Perinatal outcome in pregnancies complicated by isolated oligohydromnios at term. Annals. 2009;15(1):35-7.

20. Sowmya K, Varghese B, Borkar YB. Effect of isolated oligohydramnios in otherwise normal term pregnancy. Int J Biomed Res. 2014;5(2):98-101.

21. Madhavi K, Rao PC. Clinical Study of oligohydramnios, mode of delivery and perinatal outcome. IOSR J Dental Med Sci. 2015;14(4):6-11.

Cite this article as: Kagne $\mathrm{S}$, Chate $\mathrm{S}$. Maternal and perinatal outcome of oligohydramnios in term pregnancy in rural tertiary care centre. Int J Reprod Contracept Obstet Gynecol 2019;8:389-92. 